\title{
ЗАГАЛЬНА ХАРАКТЕРИСТИКА НАЙМЕНУВАНЬ ЗІ СФЕРИ АВІАЦЇ̈ В АНГЛІЙСЬКІЙ МОВІ
}

\begin{abstract}
Муравська С. М. Загальна характеристика найменувань зі сфери авіації в англійській мові.

У статті здійснено історичний екскурс у розвиток концепту «слово», запропоновано кілька визначень цього поняття та представлено загальну характеристику найменувань зі сфери авіації в англійській мові. Доведено 3 наведенням прикладів, що в загальній авіаційній англійській мові можна виділити певні семантичні групи.
\end{abstract}

Ключові слова: слово, лексичне значення, семантика, семантичні групи, найменування зі сфери авіації.

Муравская С. Н. Общая характеристика наименований со сферы авиации в английском языке.

В статье произведен исторический экскурс в развитие концепта «слово», представлены несколько определений этого понятия и представлена общая характеристика наименований со сферы авиации в английском языке. Доказано с приведением примеров, что в общем авиационном английском языке можна выделить определенные семантические группы.

Ключевые слова: слово, лексическое значение, семантика, семантические группы, наименования со сферы авиации.

Muravska S. M. General description of aviation notions in the English language.

Historical excursus into development of the concept "word" has been carried out, a few definitions of this notion have been presented, a general description of aviation notions in the English language has been offered in the given article. It has been proved using examples that certain semantic groups can be distinguished within general aviation English.

Key words: word, lexical meaning, semantics, semantic groups, aviation notions.

Слово цікавило мовців здавна, оскільки воно пов'язане 3 дійсністю, фіксує результати пізнавальної діяльності людини і передає ix наступним поколінням. Слово $є$ втіленням мови загалом та конкретних іiі проявів, адже мовна картина світу складається зі слів.

На думку мовознавців, поняття слова стихійно присутнє у свідомості носіїв мови. Першими текстами мовознавчого характеру були списки слів, знайдені на глиняних табличках давнього Шумера та Аккада.

На ранніх етапах розвитку мовознавства вже існував поділ слова на план вираження (фонетична і граматична структура) та план змісту (лексичне i граматичне значення). Протягом тривалого часу мовознавці надавали перевагу вивченню то плану змісту, то плану 
вираження.

Давньоіндійський мовознавець Паніні цікавився насамперед питаннями будови слова. Натомість для давньогрецьких філософів, таких як Платон та Аристотель, головною сферою вивчення була семантика слова, узаємодія між предметом, що позначається словом, та ідеєю про нього. Олександрійські граматики, а також римський учений-енциклопедист Марк Теренцій Варрон займалися морфологічними проблемами слова. Діонісій Фракійський визначав слово як «найменшу частину зв'язного мовлення».

У часи середньовіччя в Європі досліджувався насамперед семантичний аспект слова, співвідношення слова, мовлення й поняття, тоді як для арабських граматистів найбільший інтерес становила морфологічна структура. Французька граматика Пор-Рояля визначала слово як ряд «окремих звуків, 3 яких люди складають знаки для позначення своїх думок». Французькі граматики того часу виділяли формально-звукову та значеннєву сторони слова.

Сьогодні переважає системний підхід до вивчення поняття слова, який передбачає багатовекторний аналіз цього поняття. Слово досліджується як одиниця мовлення, аналізуються критерії його виділення, вивчається його змістова сторона та його функціонування в тексті.

Зважаючи на невичерпний інтерес до проблеми слова та авіацію як одну з найрозвиненіших сфер людської діяльності, було вирішено присвятити нашу статтю загальній характеристиці найменувань зі сфери авіації в англійській мові.

У XIX столітті мовознавці займалися переважно семантичною стороною слова. Велике значення мали ідеї В. фон Гумбольдта та О. Потебні про внутрішню форму слова. Семантичні процеси у слові детально досліджували М. Бреаль, Г. Пауль, М. Покровський. Розвивалася також теорія граматичної форми слова, що завдяки В. фон Гумбольдту стала основою для типологічної класифікації мов. Морфологію слова досліджували О. Потебня та П. Фортунатов. Їм належить поділ слів на самостійні і службові. Також заслуговують нашої уваги дослідження французького мовознавця А. Мейє, який виділяв три ознаки слова, а за його визначенням слово - це зв'язок певного значення 3 певною сукупністю звуків, здатною до певного граматичного вживання. Сучасний мовознавець В. Манакін досліджував концепт слова в російській та інших європейських мовах

Слово - центральна функціонально-структурна одиниця мови. 
Усі інші елементи мови існують або для слова й у слові (фонеми та морфеми), або завдяки йому (речення). Проф. В. Манакін, досліджуючи концепт слова в російській та інших європейських мовах, вказав на те, що «спочатку було Слово...» [6, с. 191-192]. На його думку, до сих пір проблемним залишається питання інтерпретації наведеної євангельської цитати. Здебільшого вона трактується однозначно й співвідноситься зі словом як найважливішою одиницею мови і мови загалом [6, с. 191-192]. Свого часу Сократ зазначав, що не кожному дається змога творити імена, а лише Богу: «Законодавець... повинен вміти втілювати у звуках та складах ім'я, причому те саме, яке у кожному випадку призначене від природи. I якщо не кожен законодавець втілює ім'я в одних і тих самих складах, це не повинно викликати у нас здивування. Не кожен коваль втілює одне й те саме знаряддя в одному і тому ж залізі» [7, с. 620-621]. Отже, кожне слово існує для позначення конкретної речі.

Існує кілька сотень визначень слова. Оскільки воно виконує номінативну функцію, О. Реформаторський стверджував, що «слово це значима самостійна одиниця мови, основною функцією якої $\epsilon$ номінація (називання)». Більш деталізоване визначення слова сформулював О. Тараненко: «слово - найменша самостійна і вільно відтворювана в мовленні відокремлено оформлена значеннєва одиниця мови, яка співвідноситься 3 пізнанням і вичленованим окремим елементом дійсності (предметом, явищем, ознакою, процесом, відношенням та ін.) i основною функцією якої $\epsilon$ позначення, знакова репрезентація цього елемента - його називання, вказування на нього або його вираження» [5, с. 183].

Професор Г. Антрушина наголошує на тому, що слово - це одиниця мовлення, яка служить потребам людського спілкування. Відповідно, слово можна визначити як одиницю спілкування [2, с. 7].

Професор І. Арнольд підкреслює, що слово $\epsilon$ основною одиницею мови. Об'єднуючи значення та форму, воно складається 3 однієї або більше морфем [3, с. 27].

Пошуки оптимального визначення слова зумовили виокремлення таких його основних ознак:

1) самостійність: слово може змінювати своє місце в межах речення, бути ізольованим, виокремленим із висловлювання, легко відтворюватися;

2) формальна цілісність: виявляється як фонетична оформленість (слова розділені паузами й об'єднані наголосом, 
фонетичною та структурною організацією), граматична оформленість (слова мають морфологічну форму й виконують синтаксичну функцію), непроникність (усередину слова не можна вставити інше слово);

3) ідіоматичність: полягає в довільності зв'язку звучання зі значенням. У похідному слові ідіоматичність виявляється і в тому, що 3 морфемного складу не можна однозначно вивести його значення. Наприклад, у слові жовток корінь жовт- і суфікс -ок не вказують на те, що їх поєднання означає «частина яйця» [5, с. 183].

Отже, слову як основній одиниці мови властиві такі ознаки:

- фонетична оформленість;

- наявність одного чи кількох лексичних значень;

- номінативність (слово виконує в мові функцію називання);

- граматична оформленість;

- виокремлення в мовленнєвому потоці;

- вільна відтворюваність у процесі мовлення (слова існують у готовому вигляді, їх не потрібно заново створювати);

- відносна вільність позиції в реченні;

- власний єдиний наголос (за винятком складних слів, які мають основний i другорядний наголоси; односкладові прийменники, сполучники і частки в поєднанні з іншими словами власного наголосу не мають);

- структурна цілісність (непроникність одного слова в інше, за винятком деяких заперечних та неозначених займенників у непрямих відмінках із прийменниками: дехто - де з ким, ніщуо - ні на чому, хтозна-який-хтозна в якому);

- переважне вживання у сполученнях слів у межах речення.

Однією 3 найважливіших характеристик слова є його лексичне значення, або лексична семантика (від гр. semantikos - який має значення) - реальний, конкретно індивідуальний зміст, тобто те, що слово називає. Лексичне значення дієслова fly буде звучати так: 1. (of a bird or an insect) to move through the air, using wings; 2. (of an aircraft or spacecraft) to move through air or space; 3 . to direct or control the flight of an aircraft; 4. to go or move quickly, to rush [8, c. 453].

Семантика мовна (давніше семасіологія) - розділ мовознавства, пов'язаний із лексикологією; вивчає значення (теж у діахронному, історичному перекрої) слів i їх складових частин, словосполук i

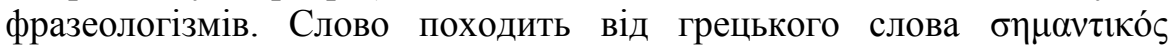

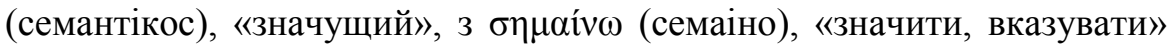


та також від би́ $\mu$ (сема), «знак, позначка, символ».

С. Дорошенко визначає семасіологію як науку про значення слів та словосполучень і зміну їх значень [4, с. 126]. На його думку, проблема значення, або семантики, слова - складна. Це зумовлено наявністю у слові двох рядів значень: лексичного й граматичного. Об’єктом семасіології $є$ лексичне значення, процеси його змін та утворення нових значень. Граматичні значення слів розглядаються граматикою.

Як правило, при аналізі семантичного поля можуть спостерігатися різні відношення. Якщо аналізуватимемо семантичне поле іменника час, то можемо говорити про такі слова: секунда, хвилина, година, доба і т. ін. Усередині семантичного поля спостерігаються кількісні відношення.

У процесі аналізу найменувань зі сфери авіації в англійській мові було встановлено специфіку семантичного поля. Маємо центральне поняття, навколо якого групуються інші (інколи складові частини виділеного явища). Наприклад, семантична група Airports передбачатиме складові частини аеропорту: runway, taxiway, tower, terminal building.

У процесі аналізу лексики з загальної авіаційної мови були виокремлені такі семантичні групи:

1. Aircrafts and their structure: windshield, fuselage, wing, slats, landing gear or undercarriage, rudder, elevator, stabilizer, engine nacelle.

2. Airports and their parts: holding bay, holding point, taxiway, runway, terminal building, tower, satellite, jetway.

3. Airport transport: FOLLOW ME van, shuttle bus, snow plough, tug, fire truck, fuel tanker, catering truck.

4. Stages of flight: start-up, push-back, taxi, line-up, take-off roll, take-off, climb, cruise, descent, approach, final approach, touch-down, land.

5. The procedure of flying for passengers: announcement, on board, check-in, check-in desk, conveyor belt, customs, customs officer, departures board, departure gate, departure lounge, duty-free, boarding pass, hand luggage, immigration officer, security guard.

6. Jobs in aviation: pilot, co-pilot, air traffic controller, flight attendant, flight engineer, airport director, reservation clerk, shuttle bus driver, marshaller, ground staff, flight crew, baggage handler, flight instructor.

7. In the air: contact, approach, control, air-ground 
communication, flight level, altitude, heading, bearing.

8. Distress and Urgency Messages: engine failure, Mayday, total electrical failure, depressurization, fire in the hold, a bomb scare, wheel well fire, a passenger with a heart attack, engine flameout, bird ingestion at initial climb, fuel endurance 10 minutes at initial stage, injuries among passengers and cabin crew after severe turbulence.

9. Cockpit Instruments: clock, DME (Distance Measuring Equipment), Airspeed Indicator, Radio Altimeter, Automatic Direction Finder, Horizontal Situation Indicator, Vertical Speed Indicator.

10. Weather words: a bank of clouds, black ice, broken clouds, build-up, CAVOK, CB (cumulonimbus), ceiling, clear air turbulence, cirrus, crosswind, down/up draught, drift, drizzle, flash of lightning, fog patches, freezing rain, gust, hail, headwind, overcast, sandstorm.

11. Words for planes: aeroplane, aircraft, twin jet, single-engined aircraft, helicopter, balloon, glider, airship, freighter, business jet, tri-jet, a jumbo.

12. Systems in aviation: TCAS (Traffic Alert and Collision Avoidance Systems), Microwave Landing Systems, SID (Standard Instrument Departure), EVS (Enhanced Vision System).

Отже, представлена загальна характеристика найменувань зі сфери авіації засвідчує велику кількість лексичних одиниць, різних за семантикою. До основних семантичних груп належать такі назви: літаків та їх будови, аеропортів і їхніх складових, транспорту в аеропорту, фаз польоту, процедури польоту для пасажирів, професії в авіації, польоту, повідомлення про аварію та біду, обладнання в кабіні літака, погодніх умов, системи в авіації. Дослідження показало, що найменування зі сфери авіації мають номінативну семантику, для них не $є$ характерним переносне значення, вони не входять до складу фразеологічних одиниць. Перспективою подальшого дослідження $\epsilon$ комплексний аналіз фразеології радіообміну, дослідження граматичних і фонетичних особливостей фразеології радіообміну.

\section{Література}

1. Авиационный английский язык для диспетчеров управления воздушным движением / Сост. Омельяненко Н. В., Витряк А. Н. // Под редакцией Витряка А. Н. Кировоград, 2008. - 272 с.

2. Антрушина Г. Б. Лексикология английского языка : [учебное пособие для студентов] / Г. Б. Антрушина, О. В. Афанасьева, Н. Н. Морозова. - М. : Дрофа, 2001. - 288 с.

3. Арнольд И. В. Лексикология современного английского языка : [учебное пособие для студентов] / И. В. Арнольд. - М. : Высшая школа, 1986. - 296 с.

4. Дорошенко С. I. Загальне мовознавство : [навчальний посібник] / 
С. І. Дорошенко. - К. : Вища школа, 2006. - 293 с.

5. Карпенко Ю. О. Вступ до мовознавства : [підручник] / Ю. О. Карпенко. - К. : Видавничий центр «Академія», 2006. - 336 с.

6. Манакин В. Н. В начале было слово / В. Н. Манакин, Н. М. Манакина // Вісник Запорізького національного університету. - 2011. - № 2. - С. 191-195.

7. Платон. Собр. соч. : в 4-х т. - Т. 1. - М. : Мысль, 1990. - 860 с.

8. Oxford Advanced Learner's Dictionary of Current English. - Oxford University Press, 1998. - 1428 p. 